\title{
MICROALBUMINURIA BESIDES TO URINARY ENZYMATIC PROTEIN LEVELS INCREASE IN DIABETIC KIDNEY DISEASE WITH TYPE II DIABETICS
}

\author{
Mosa F Osama, ${ }^{1}$ Rizk Mahmoud, ${ }^{2}$ Ahmed M Said Asmaa ${ }^{3}$ \\ ${ }^{1}$ Department of Public Health, Health Sciences College at Leith, Umm Al Qura University, KSA \\ ${ }^{2}$ Al-Leith Kidney Unit (AKU), Al-Leith General Hospital, KSA \\ ${ }^{3}$ Talkha General Hospital, Egyptian Ministry of Health and population, Egypt
}

Primljen/Received 15. 07. 2018. god.

Abstract: Background: Diabetic kidney disease (DKD) is a time progressive problem, give rise in uncontrolled Diabetics increasing risks for chronic kidney disease (CKD) and/or end-stage renal disease (ESRD). The vulnerability to renal dysfunction manifested with sudden glomerular hypofiltration associated with micro-to macroalbuminuria passing to renal failure. So that, screening of specific enzymes shifts, or urinary albumin may predict onset diabetic nephropathy. Objective: The assessment of urinary alkaline phosphatase (ALP), alanine aminopeptidase (AAP), acid phosphatase (ACP) and microalbuminuria (MAU) for type II diabetic patients. Patients and Methods: In this study, 120 type II diabetic patients were compared to 90 healthy volunteers of matched age and sex in Al-Leith General Hospital, Al-Leith Kidney Unit (AKU), Al-Leith, Makkah area, KSA in which random urine samples were collected for testing of MAU, ALP, AAP, ACP and Cr. Results: Mean values of measured biomarkers in patient group for MAU, ALP, AAP, ACP and Cr were $51.92 \mathrm{mg} / \mathrm{I}$, $41.55 \mathrm{U} / \mathrm{L}, 20.17 \mathrm{U} / \mathrm{L}, 570.10 \mathrm{U} / \mathrm{L}$ and $2.92 \mathrm{mg} / \mathrm{dl} \mathrm{VS}$ in control group were $12.59 \mathrm{mg} / \mathrm{I}, 8.84 \mathrm{U} / \mathrm{L}, 6.94 \mathrm{U} / \mathrm{L}$, $385.87 \mathrm{U} / \mathrm{L}$ and $1.07 \mathrm{mg} / \mathrm{dl}$ respectively. Additionally, there were statistically positive correlation between AAP with MAU and ALP; ACP with MAU, ALP and AAP; Cr level with MAU, ALP, AAP and ACP; on the other hand, there were positive significant correlation between duration of diabetes with all studied markers. Conclusion: Using of MAU in addition to other urinary enzymes could be beneficial non-invasive indicators for renal deterioration in type II diabetics.

Key words: Alkaline phosphatase, Alanine aminopeptidase, Acid phosphatase, Microalbuminuria, Diabetic kidney disease, Diabetes mellitus type II.
Prihvaćen/Accepted 10. 08. 2018. god.

\section{INTRODUCTION}

Diabetes mellitus (DM) is a major public health problem worldwide. Current global estimates indicate that this condition affects 415 million people and is set to escalate to 642 million by the year 2040. A further 193 million people with diabetes remain undiagnosed due to the often mild or asymptomatic nature of this condition especially in type $2 \mathrm{DM}$ (T2DM) (1). DM is a metabolic disorder characterized by chronic hyperglycemia with disturbances of carbohydrate, fat and protein metabolism resulting from defects in insulin secretion, insulin action, or both (2). The most prevalent diabetes form in human is type- 1 and type- $2 \mathrm{DM}$, the latest accounts for more than $90 \%$ of patients (3). Many patients with type- 2 diabetes are asymptomatic; there are no sharp clinical manifestations; and hence patients may remain undiagnosed for many years. Type-2 DM is characterized by two major defects, impaired insulin secretion or a decrease in its peripheral action $(4,5)$. The cause of Type-2 DM is multifactorial. Genetic susceptibility plays a crucial role in the etiology and manifestations of type-2 DM, with roots in the interaction of environmental factors; physical inactivity, obesity, ethnic, drugs and toxic agents, viral infection, and location; individual with a susceptible gene may become diabetic if environmental factors modify the expression of these genes (6). It is evident that environmental factors are playing a more increasing role in the cause of DM (7). Diabetic kidney disease (DKD) is a major cause of morbidity and mortality in diabetes. Indeed, the excess mortality of diabetes occurs mainly in individuals with diabetes and proteinuria and results not only from end-stage renal disease (ESRD) but also from cardiovascular disease, with the latter being par- 
ticularly common in patients with type 2 diabetes $(8$, 9, 10).

Approximately $20 \%$ to $40 \%$ of patients with type 1 or type 2 diabetes mellitus develop DKD. This is a clinical syndrome characterized by persistent albuminuria ( $>$ $300 \mathrm{mg} / 24 \mathrm{~h}$, or $>300 \mathrm{mg} / \mathrm{g}$ creatinine), a relentless decline in glomerular filtration rate (GFR), raised arterial blood pressure, and enhanced cardiovascular morbidity and mortality. In classical diabetic nephropathy, the first clinical sign is moderately increased urine albumin excretion (microalbuminuria: $30-300 \mathrm{mg} / 24 \mathrm{~h}$, or $30-300$ $\mathrm{mg} / \mathrm{g}$ creatinine; albuminuria grade A2). Untreated microalbuminuria will gradually worsen, reaching clinical proteinuria or severely increased albuminuria (albuminuria grade A3) over 5 to 15 years. The GFR then begins to decline, and without treatment, end-stage renal failure is likely to result in 5 to 7 years (11).

Microalbuminuria (MAU) was defined as subclinical increasing of urinary albumin, mainly due to abnormality of urine excretion of albumin between 30 and $300 \mathrm{ig} / \mathrm{ml}$ (12). MAU can be considered as a biomarker of kidney damage, end-stage renal disease (ESRD). MAU has considered as a strong candidate in the prediction of renal risk in diabeticpatients and can referred to the presence of functional and / or structural renal abnormalities that precedes and envisage the onset of GFR deterioration. The pathophysiological mechanisms underlying the presence of MAU are still not clear, though intra renal hemodynamic changes that are brought about by increased systemic blood pressure, or capillary leakiness at the glomerular level have been implicated with the latter reflecting a more generalized atherosclerotic vascular damage (13).

Albuminuria is the first sign of diabetic nephropathy, the first symptom is usually peripheral edema, which occurs at a very late stage. Regular, systematic screening for diabetic kidney disease is needed in order to identify patients at risk of or with presymptomatic diabetic kidney disease. Annual monitoring of urinary albumin-to-creatinine ratio, estimated GFR, and blood pressure is recommended. Several new biomarkers or profiles of biomarkers have been investigated to improve prognostic and diagnostic precision, but none have yet been implemented in routine clinical care. In the future such techniques may pave the way for personalized treatment (11). So that our paper aimed for assessment of urinary alkaline phosphatase (ALP), alanine aminopeptidase (AAP), acid phosphatase (ACP) and microalbuminuria (MAU) for diabetic patients type II (11).

\section{Alkaline phosphatase}

Alkaline phosphatase, which is naturally expressed along the brush border of the proximal tubule, re- duces renal inflammation via dephosphorylation of extracellular adenosine triphosphate (ATP) and adenosine diphosphate (ADP) to adenosine, which has anti-inflammatory effects. Additionally, just as intestinal alkaline phosphatase detoxifies bacterial endotoxins via dephosphorylation, alkaline phosphatase in the kidney inhibits bacterial activation of proinflammatory toll-like receptor 4 (TLR4) via dephosphorylation of their lipopolysaccharide (LPS) cell membranes (14).

\section{Alanine aminopeptidase}

Alanine aminopeptidase activity of DPP-4, an enzyme found free and in epithelial cells in most tissues, especially in the intestinal mucosa, is to cleave the $\mathrm{N}$-terminal of the incretins GLP-1 and GIP. DPP-4 is not only responsible for peptide degradation, but has also an effect on immunomodulation, cell adhesion and cell movement. The enzyme DPP-4 preferentially cleaves peptides with a proline oralanine residue in the second last aminoterminal position and removes the $\mathrm{X}$-proline and $\mathrm{X}$-alanine dipeptides from the $\mathrm{N}$-terminal end of peptides and proteins, which may have relevance in inhibiting their degradation by unspecific proteases (15).

\section{Acid phosphatases (ACPs)}

Acid phosphatases (ACPs) (EC 3.1.3.2, orthophosphoric monoester phosphohydrolases) can catalyze a remarkable variety of challenging hydrolytic enzymes that occur in multiple molecular forms with lysosomes of cells from a variety of tissues. ACP belongs to a group of enzymes that hydrolyze phosphomonoesters at acidic $\mathrm{pH}$. It is an allergen produced from bee venom component that can release histamine and induce wheal and flare reactions in sensitized humans. The general reaction mechanism catalyzed by ACP was the hydrolysis of ester phosphate linkages of organophosphate compounds, resulting in the release of inorganic phosphate (16).

\section{PATIENTS AND METHODS}

120 patients with type II diabetes were compared to 90 healthy participants of matched age and sex in Al-Leith General Hospital, Al-Leith Kidney Unit (AKU), Al-Leith, Makkah area, KSA. We declare that our study was initially approved from Alexandria Medical Research Institute ethical committee that matched with Helsinki declaration before getting any signed informed consents from both, patients and volunteers. 
The criteria of Diabetes type 2 were Hemoglobin A1c level $>6.5$ and fasting plasma glucose level $>126$ $\mathrm{mg} / \mathrm{dl}$.

- Inclusion criteria: Patients who are already diagnosed as type-2 DM, who have type-2 DM for different periods and individuals who do not suffering of renal and liver abnormality.

- Exclusion criteria: Diabetics type I, diabetics with urinary tract infections and diabetics suffering from renal or liver disease and hypertensionand CVD patients.

For all the collected samples of the study population routine urine analysis (the macroscopic and microscopic test), MAU, Alanine Aminopeptidase (AAP), Alkaline Phosphatase (ALP), Acid Phosphatase (ACP), creatinine and fast blood sugar tests were estimated.

Urinary albumin concentration was measured using the Fitzgerald ${ }^{\circledR}$ Industries International (United States) ELISA Kit, a quantitative competitive immunoassay for measurement of Human albumin in urine. Renal functional test estimation [creatinine, urea and electrolytes (Sodium, Potassium and Chloride)] - were measured using the Beckman Coulter Olympus AU480 automated chemistry analyzer.

Patients with albumin levels less than $30 \mathrm{mg} / \mathrm{g}$ of creatinine were defined as having normoalbuminuria, those with albumin levels $30-300 \mathrm{mg} / \mathrm{g}$ as having MAU. Random collected serum and urine samples were tested for ALP, AAP, ACP and Cr using.BTS 350 Semi-Automatic Analyzer Biosystems spectrophotometer.

\section{Statistical Analysis}

The collected data were coded, tabulated, and statistically analyzed using IBM SPSS (Statistical Package for Social Sciences) software version 22.0, IBM Corp., Chicago, USA, 2013. Descriptive statistics were done for quantitative data as mean $\pm \mathrm{SD}$ (standard deviation) for quantitative parametric data, while it was done for qualitative data as number and percentage. Inferential analyses for independent variables were done using Chi square test for differences between proportion, while correlations were done using Pearson's correlation for numerical parametric data. Student t-test was used to compare between two groups if the mean and SD was used. The level of significance was taken at $p$ value $\leq 0.05$, otherwise is non-significant. The p-value is a statistical measure for the probability that the results observed in a study could have occurred by chance. The discriminative power of all studied biomarkers was evaluated by receiver operating characteristic (ROC) curve analysis.

\section{RESULTS}

Table (1) summarized all demographic and clinical data of patients and control group the mean of age was $53.98 \pm 12.92$ in patient group and $51.71 \pm 12.35$ in control group without any apparent statistical significance. This study included $59(49.2 \%)$ and $48(53.3 \%)$ males and $61(50.8 \%)$ and $42(46.7 \%)$ females for pati-

Table (1). Demographic and clinical data of patient and control group

\begin{tabular}{|c|c|c|c|c|c|}
\hline & \multicolumn{2}{|c|}{ Patient } & \multicolumn{2}{|c|}{ Control } & $\mathbf{p}$ \\
\hline Age (Year) & \multicolumn{2}{|c|}{$53.98 \pm 12.92$} & \multicolumn{2}{|c|}{$51.71 \pm 12.35$} & 0.202 \\
\hline $\begin{array}{l}\text { Sex } \\
\text { Male } \\
\text { Female }\end{array}$ & $\begin{array}{l}59 \\
61 \\
\end{array}$ & $\begin{array}{l}49.2 \% \\
50.8 \%\end{array}$ & $\begin{array}{l}48 \\
42 \\
\end{array}$ & $\begin{array}{l}53.3 \% \\
46.7 \%\end{array}$ & 0.357 \\
\hline $\begin{array}{l}\text { BMI }\left(\mathbf{k g} / \mathbf{m}^{2}\right) \\
\text { Normal } \\
\text { Overweight } \\
\text { Obese } \\
\text { Morbid obese }\end{array}$ & $\begin{array}{l}20 \\
30 \\
52 \\
18\end{array}$ & $\begin{array}{l}16.7 \% \\
25.0 \% \\
43.3 \% \\
15.0 \%\end{array}$ & $\begin{array}{c}37 \\
30 \\
23 \\
0\end{array}$ & $\begin{array}{c}41.1 \% \\
33.3 \% \\
25.6 \% \\
0.0 \%\end{array}$ & $0.0001 *$ \\
\hline Systolic BP(mmHg) & \multicolumn{2}{|c|}{$130.58 \pm 12.20$} & \multicolumn{2}{|c|}{$120.17 \pm 5.85$} & $0.0001^{*}$ \\
\hline Diastolic BP (mmHg) & \multicolumn{2}{|c|}{$82.00 \pm 7.54$} & \multicolumn{2}{|c|}{$80.20 \pm 6.55$} & 0.072 \\
\hline
\end{tabular}

* Significant at $\mathrm{p}$ value $\leq 0.05$.

Table 2. Comparison between different markers in patient and control

\begin{tabular}{|l|c|c|c|}
\hline \multicolumn{1}{|c|}{ Parameters } & Patient Group & Control Group & p value \\
\hline MAU mg/l & $51.92 \pm 23.78$ & $12.59 \pm 4.86$ & $0.0001^{*}$ \\
\hline ALP U/L & $41.55 \pm 23.87$ & $8.84 \pm 4.50$ & $0.001^{*}$ \\
\hline AAP U/L & $20.17 \pm 8.07$ & $6.94 \pm 1.54$ & $0.0002^{*}$ \\
\hline ACP U/L & $570.10 \pm 254.52$ & $385.87 \pm 180.28$ & $0.0001^{*}$ \\
\hline Cr $\mathbf{~ m g / d L ~}$ & $2.92 \pm 1.44$ & $1.07 \pm 0.30$ & $0.013^{*}$ \\
\hline
\end{tabular}

* Significant at $\mathrm{p}$ value $\leq 0.05$. 

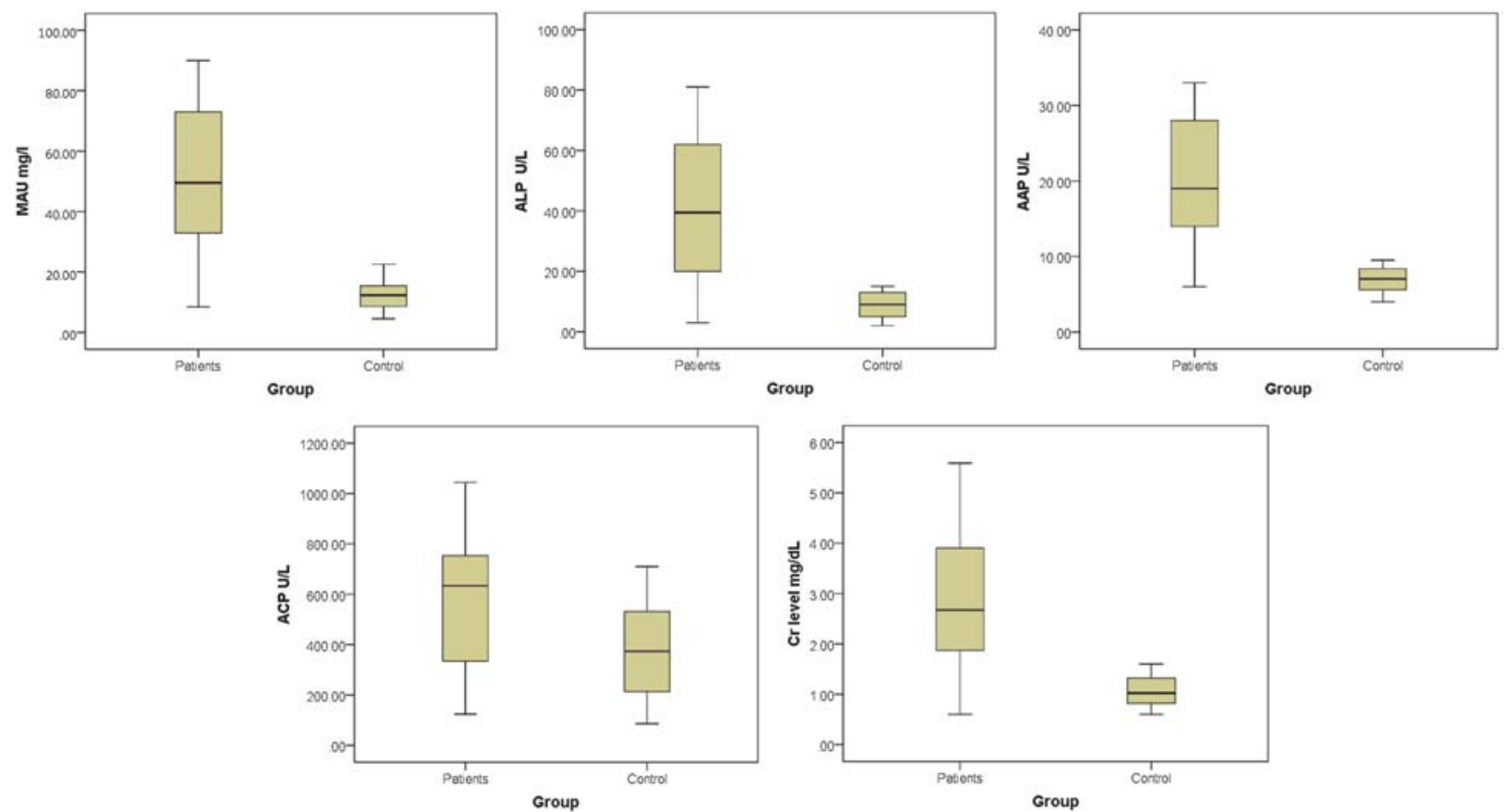

Figure 1. Comparison between different biomarkers in patient and control groups

ent and control groups respectively with $\mathrm{p}=0.357$. Dependent on BMI, patients were variably distributed as normal $(17.6 \%)$, overweight $(25.0 \%)$, obese $(43.3 \%)$ and morbid obese $(15.0 \%)$ with $\mathrm{p}<0.001$. The systolic BP mean $(\mathrm{mmHg})$ was $(130.58 \pm 12.20)$ in patient group overcoming that in control group $(120.17 \pm 5.85)$ with $\mathrm{p}<0.001$. While the mean of diastolic blood pressure $(\mathrm{mmHg})$ was $82.00 \pm 7.54$ and $80.20 \pm 6.55$ for patient and control groups with no statistical significant differences.

Comparison between different studied parameters in patient and control groups were presented in Table 2 and Figure 1, showing significant higher values of microalbuminuria (MAU), alkaline phosphatase (ALP), alanine aminopeptidase (AAP), acid phosphatase (ACP) and creatinine levels $(\mathrm{Cr})$ in patient group than in control group.

Table 3 epitomized the correlation between duration of disease and all different studied markers, illustrating that, there were statistically positive correlations between levels of AAP with MAU and ALP; ACP with MAU, ALP and AAP; Cr with MAU, ALP, AAP and ACP; on the other hand, there were positive significant correlations between the duration of diabetes with all studied biomarkers.

Relationships between levels of different biomarkers in patient group and type of medications were perfectly recapped as in Table 4, indicating that means of MAU, ALP, AAP, ACP, Cr levels were two fold in pati-

Table 3. Correlation between duration of disease and different studied biomarkers

\begin{tabular}{|l|c|c|c|c|c|c|}
\hline \multicolumn{2}{|c|}{} & $\begin{array}{c}\text { MAU } \\
\mathrm{mg} / 1\end{array}$ & $\begin{array}{c}\text { ALP } \\
\text { U/L }\end{array}$ & $\begin{array}{c}\text { AAP } \\
\text { U/L }\end{array}$ & $\begin{array}{c}\text { ACP } \\
\text { U/L }\end{array}$ & $\begin{array}{c}\text { Cr level } \\
\text { mg/dL }\end{array}$ \\
\hline \multirow{2}{*}{ ALP U/L } & $\mathrm{r}$ & .998 & & & & \\
\cline { 2 - 7 } & $\mathrm{p}$-value & $0.001^{*}$ & & & & \\
\hline \multirow{3}{*}{ AAP U/L } & $\mathrm{r}$ & .998 & .995 & & & \\
\cline { 2 - 7 } & $\mathrm{p}$-value & $0.001^{*}$ & $0.001^{*}$ & & & \\
\hline \multirow{2}{*}{ ACP U/L } & $\mathrm{r}$ & .986 & .989 & .983 & & \\
\cline { 2 - 7 } & $\mathrm{p}$-value & $0.001^{*}$ & $0.001^{*}$ & $0.001^{*}$ & & \\
\hline \multirow{2}{*}{ Cr level mg/dL } & $\mathrm{r}$ & .991 & .991 & .989 & .977 & \\
\cline { 2 - 8 } & $\mathrm{p}$-value & $0.001^{*}$ & $0.001^{*}$ & $0.001^{*}$ & $0.001^{*}$ & \\
\hline \multirow{2}{*}{ Duration of diabetes } & $\mathrm{r}$ & .878 & .880 & .872 & .873 & .859 \\
\cline { 2 - 8 } & $\mathrm{p}$-value & $0.001^{*}$ & $0.001^{*}$ & $0.001^{*}$ & $0.001^{*}$ & $0.001^{*}$ \\
\hline
\end{tabular}

* Significant at $\mathrm{p}$ value $\leq 0.05$. 
Table 4. Association between different biomarkers levels in patient group and type of medication

\begin{tabular}{|l|c|c|c|}
\hline \multirow{2}{*}{} & \multicolumn{2}{|c|}{ Type of medication } & \multirow{2}{*}{ p } \\
\cline { 2 - 3 } & Hypoglycemic agents' Tabs & Insulin injections & $0.0001^{*}$ \\
\hline MAU mg/l & $39.45 \pm 16.35$ & $81.03 \pm 6.65$ & $0.0002^{*}$ \\
\hline AAP U/L & $29.12 \pm 16.56$ & $70.56 \pm 7.19$ & $0.0035^{*}$ \\
\hline ACP U/L & $15.89 \pm 5.49$ & $30.14 \pm 1.99$ & $0.001^{*}$ \\
\hline Cr mg/dL & $448.70 \pm 198.00$ & $853.36 \pm 96.88$ & $0.0021^{*}$ \\
\hline
\end{tabular}

* Significant at $\mathrm{p}$ value $\leq 0.05$.

Table 5. Relation between different markers in patient group and the regularity of taking medication

\begin{tabular}{|l|c|c|c|}
\hline \multirow{2}{*}{ Parameters } & \multicolumn{2}{|c|}{ Treatment regularity } & \multirow{2}{*}{ p } \\
\cline { 2 - 3 } & Regular & Irregular & $0.0041^{*}$ \\
\hline MAU mg/l & $26.37 \pm 8.69$ & $66.72 \pm 15.79$ & $0.0001^{*}$ \\
\hline ALP U/L & $15.50 \pm 8.07$ & $56.63 \pm 15.44$ & $0.0021^{*}$ \\
\hline AAP U/L & $11.61 \pm 3.30$ & $25.12 \pm 5.43$ & $0.0041^{*}$ \\
\hline ACP U/L & $283.68 \pm 107.67$ & $735.92 \pm 141.95$ & $0.0021^{*}$ \\
\hline Cr $\mathbf{~ m g / d L ~}$ & $1.46 \pm 0.55$ & $3.76 \pm 1.07$ & \\
\hline
\end{tabular}

* Significant at $\mathrm{p}$ value $\leq 0.05$.

Table 6. Prediction values of different markers in DKD with type II diabetics

\begin{tabular}{|c|c|c|c|c|c|c|c|c|}
\hline \multirow{2}{*}{$\begin{array}{c}\text { Test Result } \\
\text { Variable(s) }\end{array}$} & Area & P value & Cut off value & Sensitivity & \multirow{2}{*}{ Specificity } & \multirow{2}{*}{ Accuracy } & \multicolumn{2}{|c|}{ Asymptotic 95\% C.I. } \\
\cline { 5 - 9 } & & & & & & Lower & Upper \\
\hline MAU mg/l & 0.966 & 0.00012 & 32.0 & 98.0 & 95.4 & 96.0 & .943 & .988 \\
\hline ALP U/L & 0.906 & 0.00011 & 28.0 & 90.5 & 88.9 & 92.0 & .865 & .948 \\
\hline AAP U/L & 0.955 & 0.00025 & 14.2 & 91.3 & 92.6 & 91.0 & .926 & .985 \\
\hline ACP U/L & 0.718 & 0.016 & 420.6 & 68.0 & 72.2 & 69.0 & .651 & .786 \\
\hline Cr $\mathbf{~ m g / d L ~}$ & 0.888 & 0.0036 & 1.52 & 81.0 & 90.0 & 84.0 & .840 & .936 \\
\hline
\end{tabular}

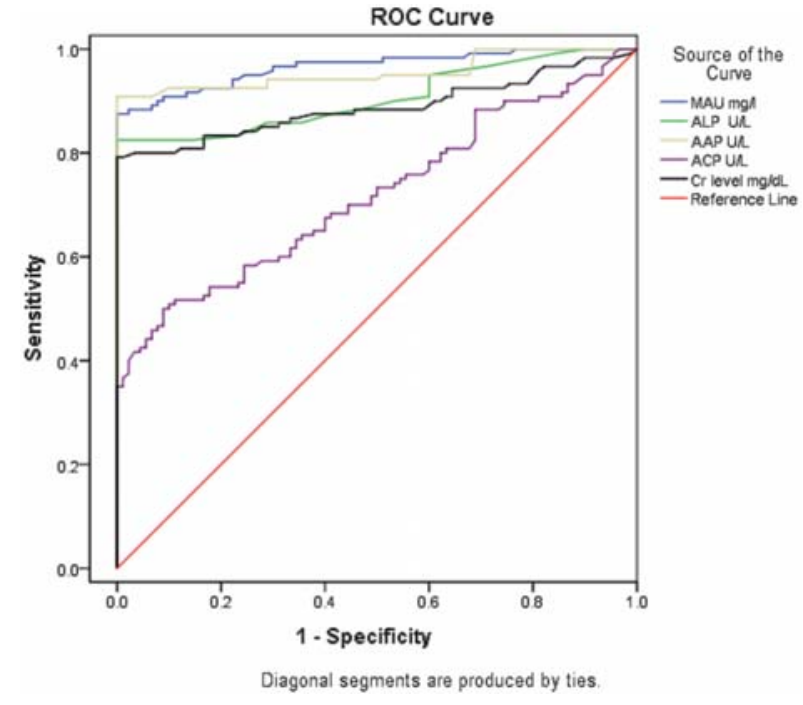

Figure 2. ROC curve of different studied markers in predict the $D K D$ ents using insulin injections than hypoglycemic agents' tabs approximately with significant $\mathrm{p}$ values.

Moreover, levels of different biomarkers in patients group and the regularity of use of medication were presented in Table 5, elucidating that means of MAU, ALP, AAP, ACP, Cr levels were significantly reduced upon regular ongoing treatment compared to irregular one.

Evaluation of the diagnostic performance of all studied biomarkers against DKD using ROC curve including; sensitivity, specificity and accuracy indicated that MAU was highly predictive followed by AAP as shown in Table 6 and Figure 2.

\section{DISCUSSION}

Previous studies showed shown that microalbuminuria (MAU) is an independent risk factor for kidney diseases in diabetics, hypertensive patients and in the gene- 
ral population $(17,18)$. However, the correlation of MAU with the severity of kidney disease in diabetic patients had not been addressed in detail. This study aimed to assessment of urinary alkaline phosphatase (ALP), alanine aminopeptidase (AAP), acid phosphatase (ACP) and microalbuminuria (MAU) for type II diabetic patients. 100 patients type II diabetic compared to 51 healthy volunteers of matched age and sex.

In our study, most of patient's groups was over weight $(25.0 \%)$ and obese (43.3\%) with significant differences. The mean of systolic blood pressure was $130.58 \pm 12.20$ and $120.17 \pm 5.85$ for patients and control groups respectively, patients group have values statistically higher than control group.

In agreement with our study, Al-Houli NH et al (14) and GO AS et al. (15) reviewed aspects of the association of diabetes and obesity with renal disease, emphasizing that CKD and albuminuria are associated with increased rates of cardiovascular disease (CVD) and mortality, and should be considered part of the cardiovascular risk factors in persons with diabetes. Lorenzo (16), found that the development of glomerular filtration rate $<60 \mathrm{~mL} / \mathrm{min}$ per $1.73 \mathrm{~m}^{2}$ was associated with increased fasting insulin, triglycerides, free fatty acids, obesity, and uric acid and also with antihypertensive treatment, although not with waist circumference, controlling for age, sex, ethnicity, blood pressure, glucose, and C-reactive protein in nondiabetic persons. This points towards the association of CKD with the risk of development of diabetes (16).

In this study, there were statistically positive correlation between AAP with MAU and ALP; ACP with MAU, ALP and AAP; Cr level with MAU, ALP, AAP and ACP; on the other hand, there were positive significant correlation between duration of diabetes with all studied markers. Also, significant differences were found in a comparison between the means of the 5 markers in patient group.

These results indicated that these markers could be of interest to use in early detection of DKD in the preclinical stage. Otherwise, it was recommended for using such markers as early predictors of gradual deterioration of the transplanted kidney that perhaps lead eventually to graft rejection (19). Inverse correlation of $\mathrm{Cr}$ level was found between the DM and the control group (decreased in the patients compared to control group). This could be explained by the fact that glomerular hyperfiltration develops at initial stages of the disease (20). The same results were found in Lary SA study (21), who studied one hundred and fifty-five subjects, not under medication and without clinical evidence of renal disease, hypertension, or diabetes mellitus were used as controls. Two urinary enzymes, $\mathrm{N}$-acetyl-beta-D-glucosaminidase (NAG) and AAP were measured in the urine, together with total protein and creatinine concentration. MAU, glucose and $\mathrm{pH}$ were measured using test strips. Increased levels of both NAG and AAP were found in the diabetic subjects. Increased excretion of both enzymes with MAU was found in hypertensive groups suggesting the more prevalent renal complications in the studied groups (21).

Currie Get al, (22) showed that assessment of urinary alkaline phosphatase, alanine aminopeptidase and micro/macro albuminuria for insulin and regular treatment patients very useful to predict kidney failure, the development of new technologies had led to exciting possibilities in the search for ideal biomarkers for DN but, despite of huge enormous number of studies, none of them demonstrated so far, the superiority to albuminuria. While biomarker research in the preclinical setting is advancing, none of those biomarkers described above was neither be validated nor available commercially for clinical use and any association with nonalbuminuric DN that might reflect a separate disease process still unexplained. All such potentially interesting markers require further large-scale validation in prospective clinical studies to determine whether they can make the transition from bench to bedside (22).

Although, all studied markers exhibited significant high sensitivity, specificity and accuracy but, the higher one was MAU followed by AAP. This result was the same as Lee M et al study indicated MAU sensitivity superfat if combined with serum creatinine (23). So that calculation of the microalbumin: creatinine ratio might increase the predictive value of MAU.

\section{CONCLUSION}

The findings of this study reflected the importance of microalbuminuria and urinary enzymes as non-invasive tests to find diabetic patients who are at risk to develop renal disease or kidney failure, also the combination of elevated MAU and AAP may indicate DKD with a sensitivity of $98 \%$.
Abbreviations
DKD - Diabetic kidney disease
CKD - Chronic kidney disease
ESRD - End-stage renal disease
ALP - Alkaline phosphatase
AAP - Alanine aminopeptidase
ACP - Acid phosphatase
MAU - Microalbuminuria
Cr - Creatinine
DMII - Diabetes mellitus type II
DM - Diabetes mellitus
GFR - Glomerular filtration rate 


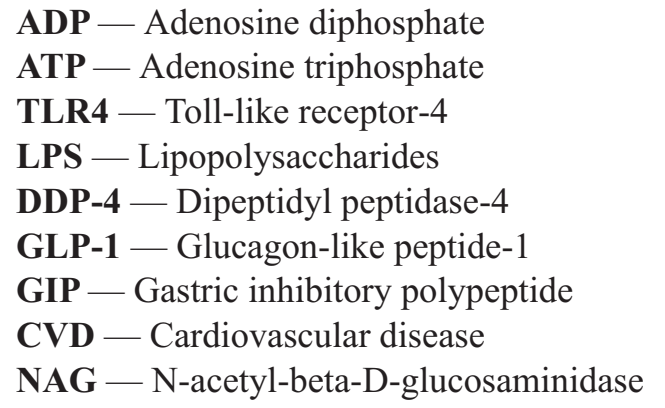

\section{DECLARATION OF INTEREST}

The autors declare that there are no conflicts of interests.

\section{Licensing}

This work is licensed under a Creative Commons Attribution 4.0 International (CC BY 4.0) License.

\title{
Sažetak
}

\section{PORAST NIVOA MIKROALBUMINURIJE UZ URINARNE ENZIME KOD DIABETIČNE BOLESTI BUBREGA}

\author{
Mosa F Osama, ${ }^{1}$ Rizk Mahmoud, ${ }^{2}$ Ahmed M Asmaa ${ }^{3}$ \\ ${ }^{1}$ Department of Public Health, Health Sciences College at Leith, Umm Al Qura University, KSA \\ ${ }^{2}$ Al-Leith Kidney Unit (AKU), Al-Leith General Hospital, KSA \\ ${ }^{3}$ Talkha General Hospital, Egyptian Ministry of Health and population, Egypt
}

Uvod: Diabetična bolest bubrega (DKD) je progresivan problem posebno kod nekontrolisanih diabetičara koji povećava rizik za nastanak CKD i/ili ESRD. Renalna disfunkcija manifestovana iznenadnom glomerularnom hipofiltracijom sa mikro ka makroalbuminuriji prelazi u bubrežnu insuficijenciju. Prema tome, skriningom specifičnih enzima ili albumina u urinu može se predvideti diabetična nefropatija.

Cilj: Procena značaja urinarne alkalne fosfataze (ALP), alanin aminopeptidaze (AAP), acido fosfataze (ACP) i mikroalbuminurije (MAU) kod pacijenata sa diabetesom Tip II.

Pacijenti i Metode: U ovoj studiji je 120 pacijenata sa diabetesom Tip II poređeno sa 90 zdravih volontera uparenih godina i pola. Ispitivanje je izvršeno u

\section{REFERENCES}

1. Al-Lawati JA. Diabetes mellitus: a local and global public health emergency. Oman Med J. 2017; 32(3): 177-9.

2. Hameed I, Masoodi S, Mir S, Nabi M, Ghazanfar K, Ganai B. Type 2 diabetes mellitus: From a metabolic disorder to an inflammatory condition. World J Diabetes. 2015; 6(4): 598-612.

3. Wu Y, Ding Y, Tanaka Y, Zhang W. Risk factors contributing to Type 2 Diabetes and recent advances in the treatment and prevention. Int J Med Sci. 2014; 11(11): 1185-200.

4. Malecki MT. Type-2 Diabetes mellitus and its complications: from the molecular biology to the clinical practice. Rev Diabet Stud. 2004; 1(1): 5-8.

5. Sutherland C, Campbell DG, Cohen P. Identification of insulin-stimulated protein kinase-1 as the rabbit equivalent of rskmo-2. Identification of two threonines phosphorylated during activation by mitogen-activated protein kinase. Eur J Biochem. 1993; 212(2): 581-8.

6. Trevisan R, Vedovato M, Tiengo A. The epidemiology of diabetes mellitus. Nephrol Dial Transplant. 1998; 13(suppl 8): 2-5.
Al-Leith Opštoj bolnici, Odeljenju nefrologije, Al-Leith, u Saudijskoj Arabiji, gde su slučajni uzorci urina sakupljani za određivanje MAU, ALP, AAP, ACP i Cr.

Rezultati: srednje vrednosti određivanih biomarkera u grupi pacijenata za MAU, ALP, AAP, ACPi Cr bile su: 51,92 mg/I, 41,55 U/L, 20,17 U/L, 570,10 U/Li $2,92 \mathrm{mg} / \mathrm{dl}$, a u kontrolno jgrupi $12,59 \mathrm{mg} / \mathrm{I}, 8,84 \mathrm{U} / \mathrm{L}$, $6,94 \mathrm{U} / \mathrm{L}, 385,87 \mathrm{U} / \mathrm{Li} 1,07 \mathrm{mg} / \mathrm{dl}$.

Zaključak: Ispitivanje MAU uz specifične urinarne enzime može biti koristan neinvazivni indikator za bubrežnu insuficijenciju kod pacijenata sa diabetesom Tip II.

Ključne reči: Alkalna fosfataza, Alanin aminopeptidaza, Kisela fosfataza, Mikroalbuminurija, Dijabetična bolest bubrega, Dijabetes melitus tip II.

7. Murea M, Ma L, Freedman BI. Genetic and environmental factors associated with type 2 diabetes and diabetic vascular complications Rev Diabet Stud. 2012; 9(1): 6-22.

8. Afkarian M, Zelnick LR, Hall YN, Heagerty PJ, Tuttle $\mathrm{K}$, Weiss NS, et al. Clinical manifestations of kidney disease among US adults with diabetes, 1988-2014. JAMA. 2016; 316(6): 602-10.

9. Borch-Johnsen K. The prognosis of insulin-dependent diabetes mellitus. An epidemiological approach. Dan Med Bull. 1989; 36(4): 336-48.

10. de Boer IH, Gao X, Cleary PA, Bebu I, Lachin JM, Molitch ME, et al. Albuminuria changes and cardiovascular and renal outcomes in type 1 diabetes: The DCCT/EDIC Study. Clin J Am Soc Nephrol. 2016; 11(11): 1969-77.

11. Persson F, Rossing P. Diagnosis of diabetic kidney disease: state of the art and future perspective. Kidney International Supplements. 2018; 8(1): 2-7.

12. Poudel B, Yadav BK, Nepal AK, Jha B, Raut KB. Prevalence and association of microalbuminuria in essential hypertensive patients. N Am J Med Sci. 2012; 4(8): 331-5. 
13. Futrakul N, Sridama V, Futrakul P. Microalbuminuria: a biomarker of renal microvascular disease. Ren Fail. 2009; 31(2): 140-3.

14. Al-Houli NH. Leptin and Soluble Leptin Receptor (OB-Re). Among Obese Patients in Gaza Strip. A dissertation submitted as part of requirement for the degree of Masters of Biological Sciences in Medical. Technology in IUG. 2006.

15. Go AS, Chertow GM, Fan D, Mc Culloch CE, Hsu CY. Chronic kidney disease and the risks of death, cardiovascular events, and hospitalization. N Engl J Med. 2004; 351(13): 1296-305.

16. Bloomgarden ZT. Diabetic nephropathy. Diabetes Care. 2008 ; 31(4): 823-7.

17. Anavekar NS, Gans DJ, Berl T, Rhode RD, Cooper W, Bhaumik A, et al.Predictors of cardiovascular events in patients with type 2 diabetic nephropathy and hypertension: a case for albuminuria Kidney Int Suppl. 2004 ;92: S50-5.

18. Park HY, Schumock GT, Pickard AS, Akhras K. A structured review of the relationship between microalbuminuria and cardiovascular events in patients with diabetes mellitus and hypertension. Pharmacotherapy. 2003; 23(12): 1611-16.

19. Salvadori M, Tsalouchos A. Biomarkers in renal transplantation: An updated review. World J Transplant. 2017; 7(3): 161-78.

20. Uslu S, Efe B, Alatas O, Kebapçi N, Colak O, Demirüstü $\mathrm{D}$, et al. Serum cystatin $\mathrm{C}$ and urinary enzymes as screening markers of renal dysfunction in diabetic patients. J Nephrol. 2005; 18(5): 559-67.

21. Lary SA. Urinary enzymes and microalbuminuria as indicators of renal involvement in patients with diabetes mellitus in Saudi Arabia. Saudi J Kidney Dis Transpl. 2004; 15(1): 18-26.

22. Currie G, McKay G, Delles C. Biomarkers in diabetic nephropathy: Present and future. World J Diabetes. 2014; 5(6): 763-76.

23. Lee MK, Han KD, Lee JH, Sohn SY, Hong OK, Jeong JS, et al. Normal-to-mildly increased albuminuria predicts the risk for diabetic retinopathy in patients with type 2 diabetes. Scientific Reports. 2017; 7(1): 11757.

\section{Correspondence to / Autor za korespondenciju}

Mosa F Osama

Assistant Professor of Clinical Biochemistry

Department of Public Health, Health Sciences College at Leith

Umm Al Qura University, KSA

Tel: +966541485058;

Email: drosama2030@gmail.com 